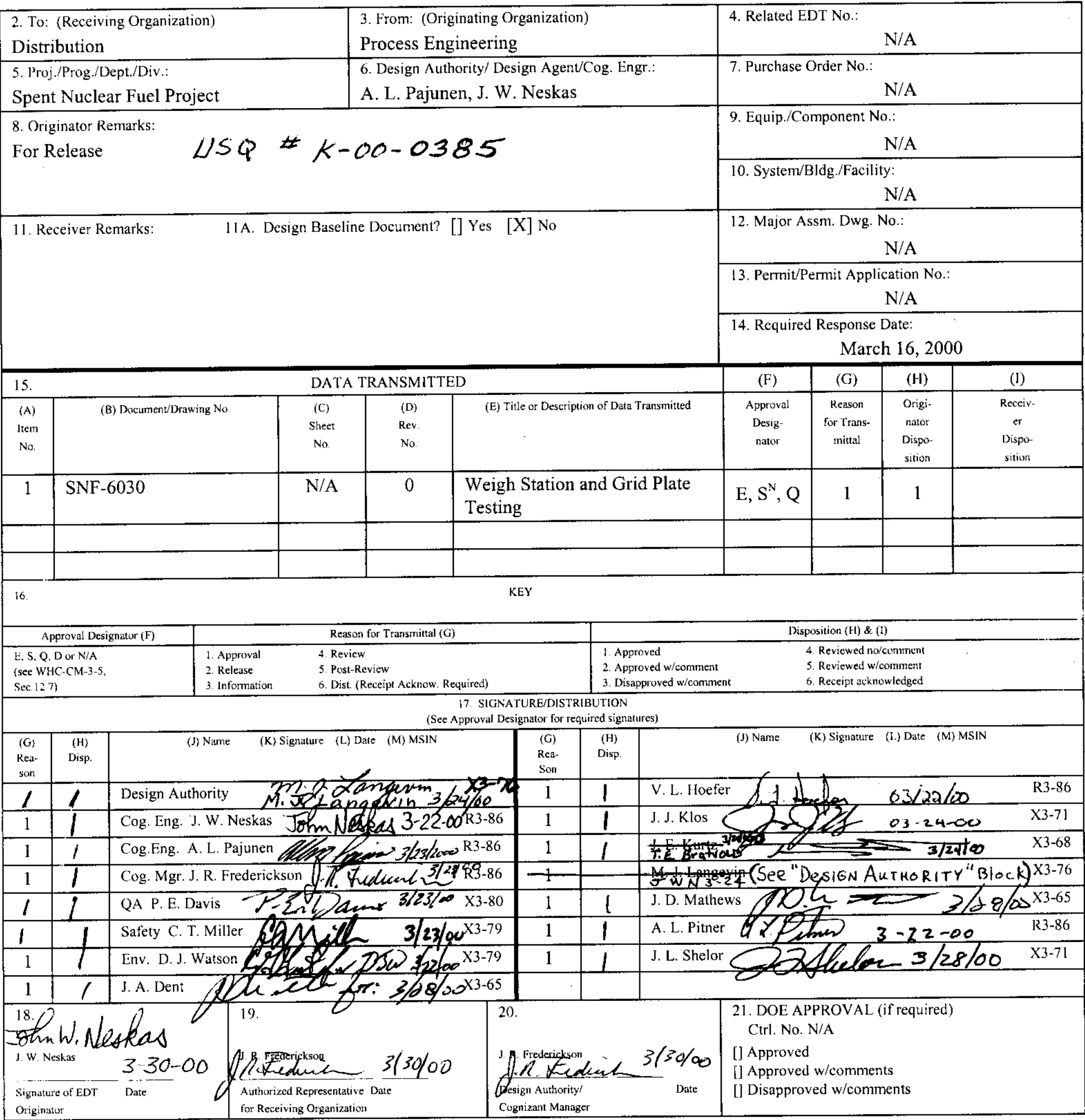




\section{DISTRIBUTION SHEET}

\begin{tabular}{|c|c|c|c|c|c|}
\hline \multirow{2}{*}{$\begin{array}{l}\text { To } \\
\text { Distribution }\end{array}$} & \multirow{2}{*}{\multicolumn{3}{|c|}{$\begin{array}{l}\text { From } \\
\text { Process Engineering }\end{array}$}} & \multicolumn{2}{|l|}{ Page 1 of 1} \\
\hline & & & & \multicolumn{2}{|l|}{ Date $3 / 15 / 00$} \\
\hline \multicolumn{4}{|l|}{ Project Title/Work Order } & \multicolumn{2}{|c|}{ EDT No. 629001} \\
\hline Weigh Station and Grid Plate Testing & & & & \multicolumn{2}{|l|}{ ECN No. N/A } \\
\hline Name & MSIN & $\begin{array}{c}\text { Text } \\
\text { With All } \\
\text { Attach. }\end{array}$ & $\begin{array}{l}\text { Text } \\
\text { Only }\end{array}$ & $\begin{array}{l}\text { Attach./ } \\
\text { Appendix } \\
\text { Only }\end{array}$ & $\begin{array}{l}\text { EDT/ECN } \\
\text { Only }\end{array}$ \\
\hline
\end{tabular}

Spent Nuclear Fuel Project

P. E. Davis

J. A. Dent

J. R. Frederickson

V. L. Hoefer

J. J. Klos

J. E. Kurtz

M. J. Langevin

J. D. Mathews

C. T. Miller

W. C. Miller

J. W. Neskas

A. L. Pajunen

A. L. Pitner

J. L. Shelor

D. J. Watson

SNF Project Files

SNF Project Procedures

SNF Project Training

$\begin{array}{ll}\text { X3-80 } & \text { X } \\ \text { X3-65 } & \text { X } \\ \text { R3-86 } & \text { X } \\ \text { R3-86 } & \text { X } \\ \text { X3-71 } & \text { X } \\ \text { X3-68 } & \text { X } \\ \text { X3-76 } & \text { X } \\ \text { X3-65 } & \text { X } \\ \text { X3-79 } & \text { X } \\ \text { R3-11 } & \text { X } \\ \text { R3-86 } & \text { X } \\ \text { R3-86 } & \text { X } \\ \text { R3-86 } & \text { X } \\ \text { X3-71 } & \text { X } \\ \text { X3-79 } & \text { X } \\ \text { R3-11 } & \text { X } \\ \text { X3-86 } & \\ \text { S2-45 } & \end{array}$

$\mathrm{X}$ 
SNF-6030

Revision 0

\section{Weigh Station and Grid Plate Testing}

Prepared for the U.S. Department of Energy Assistant Secretary for Environmental Management

Project Hanford Management Contractor for the

U.S. Department of Energy under Contract DE-AC06-96RL13200

Fluor Hanford

P.O. Box 1000

Richland, Washington 
SNF-6030

Revision 0

EDT 629001

\title{
Weigh Station and Grid Plate Testing
}

\author{
A. L. Pajunen \\ Fluor Hanford \\ J. W. Neskas \\ WASTREN
}

Date Published

March 2000

Prepared for the U.S. Department of Energy

Assistant Secretary for Environmental Management

Project Hanford Management Contractor for the

U.S. Department of Energy under Contract DE-AC06-96RL13200

\section{Fluor Hanford}

P.O. Box 1000

Richland, Washington
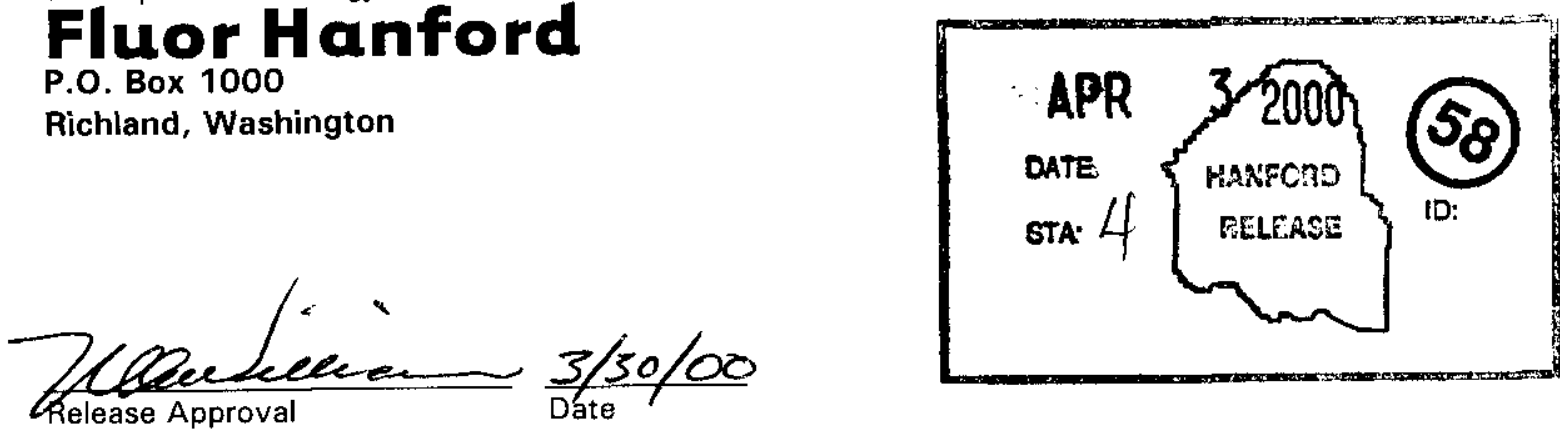


\section{TRADEMARK DISCLAIMER}

Reference herein to any specific commercial product, process, or service by trade name, trademark, manufacturer, or otherwise, does not necessarily constitute or imply its endorsement, recommendation, or favoring by the United

States Government or any agency thereof or its contractors or subcontractors.

This report has been reproduced from the best available copy. Available in paper copy and microfiche.

Available electronically at $h$ ttp://www.doe.gov/bridge. Available for a processing fee to the U.S. Department of Energy and its contractors, in paper, from:

U.S. Department of Energy

Office of Scientific and Technical Information

P.O. Box 62

Oak Ridge, TN 37831-0062

phone: $865-576-8401$

fax: 865-576-5728

email: reports@adonis.osti.gov(423) 576-8401

Printed in the United States of America 


\section{Table of Contents}

\begin{tabular}{|c|c|}
\hline $\begin{array}{l}1.0 \\
2.0\end{array}$ & $\begin{array}{l}\text { INTRODUCTION } \\
\text { OBJECTIVE }\end{array}$ \\
\hline 0 & SCOPE. \\
\hline 0 & DESCRIPTION OF TEST. \\
\hline 4.1 & 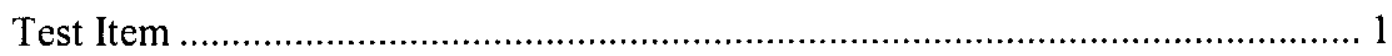 \\
\hline 4.2 & Test Environment... \\
\hline 4.3 & Equipment and Facilities............... \\
\hline 4.4 & Data....... \\
\hline 4.5 & Criteria/Constraints ................ \\
\hline 0 & EXPECTED RESULTS......... \\
\hline 0 & TEST PROCEDURE \\
\hline .0 & 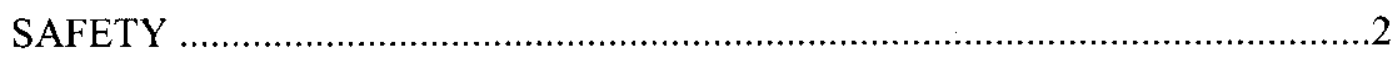 \\
\hline 0 & QUALITY ASSURANCE \\
\hline 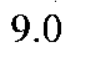 & ORGANIZATION AND FUNCTION RESPONSIBILITIES \\
\hline 0 & 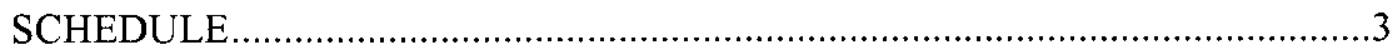 \\
\hline .0 & REPORTS. \\
\hline & REFERENCES \\
\hline & DATA SHEETS ......................... \\
\hline
\end{tabular}

\section{List of Acronyms}

$\begin{array}{ll}\text { AJHA } & \text { Automated Job Hazard Analysis } \\ \text { ETD } & \text { Engineering Test Director } \\ \text { FRS } & \text { Fuel Retrieval System } \\ \text { JCS } & \text { Job Control System } \\ \text { OTD } & \text { Operations Test Director } \\ \text { PAT } & \text { Pre-Operational Acceptance Test } \\ \text { PCM } & \text { Primary Cleaning Machine } \\ \text { PSI } & \text { Phased Startup Initiative } \\ \text { QA } & \text { Quality Assurance } \\ \text { QC } & \text { Quality Control } \\ \text { OCRWM } & \text { Office of Civilian Radioactive Waste Mangement } \\ \text { OTD } & \text { Operations Test Director } \\ \text { TE } & \text { Test Engineer }\end{array}$


SNF-6030, Rev. 0

\section{WEIGH STATION AND GRID PLATE TESTING}

\section{EXECUTIVE SUMMARY}

The purpose of this test plan is to describe the Phased Startup Initiative (PSI) testing of the weigh station and grid plate in the $105 \mathrm{~K}$ West Basin. The test procedure is provided as Appendix A in the pre-operational acceptance test PAT format. It is necessary to successfully demonstrate this testing before $\mathrm{N}$ Reactor fuel is processed through the Fuel Retrieval System (FRS) in Phase 3.

\subsection{INTRODUCTION}

The purpose of this test is to verify that the Shortened Fuel Canister Hook with Certified Scale (i.e. Weigh Station) can be used to weigh an empty canister from the Canister Well and the empty Primary Cleaning Machine (PCM) Strainer Basket from the process table. Drawing H-1-84835, "Canister Handling Hook for Fuel Retrieval System Process Table," provides details of the Shortened Fuel Canister Hook. It is also necessary to verify that the grid plate can be lifted and tilted over a canister in the canister well. This testing shall be performed before $\mathrm{N}$ Reactor fuel is processed through the FRS in Phase 3. The Phase 3 Test will repeatedly weigh fuel and scrap canisters and the PCM strainer basket containing $\mathrm{N}$ Reactor fuel (Pajunen, et. al, 2000). Advance testing of this weigh station will ensure that accurate fuel weight data can be recorded in the Phase 3 Test.

This document satisfies the requirements in EN-6-031-00, "Testing Process" for a test plan, test specification and test procedure.

\subsection{OBJECTIVE}

The goal of this test is to demonstrate that the Shortened Fuel Canister Hook and Certified Scale can weigh a canister from the Canister Well and weigh the PCM Strainer Basket from the Process Table. Another goal is to lift the Grid Plate from the Process Table and tilt it over a canister in the Canister Well.

\subsection{SCOPE}

No N Reactor fucl is involved with this test. Mock fuel is not necessary for this test.

\subsection{DESCRIPTION OF TEST}

\subsection{Test Item}

The Shortened Fuel Canister Hook with Certified Scale and the Grid Plate are the items tested. The test shall be contralled and scheduled by the Job Control System (JCS). 
SNF-6030, Rev. 0

\subsection{Test Environment}

The $105 \mathrm{~K}$ West Basin is the test environment.

\subsection{Equipment and Facilities}

The equipment used includes the Shortened Fuel Canister Hook with Certified Scale (Weigh Station), used in conjunction with the $105 \mathrm{~K}$ West Facility Fuel Handling System. The Grid Plate is lifted and tilted with tools such as pole hooks.

\subsection{Data}

The test data shall be recorded on blank lines provided in Appendix A, "Test Procedure".

\subsection{Criteria/Constraints}

This test shall be conducted in accordance with the requirements of the Operational Authorization Basis at the $105 \mathrm{~K}$ West Basins.

\subsection{EXPECTED RESULTS}

5.1 The Weigh Station can be used to lift the canister from the Canister Well, display the weight, and return the canister to the Canister Well.

5.2 The Weigh Station can be used to lift the PCM Strainer from Process Table, display the weight, and return the PCM Strainer to the Process Table.

5.3 The weight measurement of a canister submerged in water is compared with the pre-test canister weight in order to determine the weighing uncertainty of the integrated system.

5.4 The Grid Plate can be lifted and tilted over a canister in the canister well, in order to simulate the transfer of scrap from the grid plate to the canister.

\subsection{TEST PROCEDURE}

The Test Procedure is provided as Appendix A.

\subsection{SAFETY}

All personnel involved with the performance of this test shall attend a Pre-job Safety Briefing and sign the Pre-Job Safety Briefing Signature Sheet provided at the end of Appendix A. The Pre-Job Safety Briefing shall include a review of the Automated Job Hazard Analysis (AJHA), ALARA requirements and Criticality requirements (including Criticality Postings). 


\subsection{QUALITY ASSURANCE}

The canister used in this test shall be accepted by Quality Assurance (QA) and approved for use in the Basin (acceptance tagged). A Quality Control (QC) certification of the grid squares on the Grid Plate shall be provided (acceptance tagged). These testing activities do not require an Office of Civilian Radioactive Water Management (OCRWM) review.

\subsection{ORGANIZATION AND FUNCTION RESPONSIBILITIES}

These tests shall be performed as a portion of the PSI in preparation for Phase 3 testing. The on-duty Shift Manager has overall responsibility for activities within the $105 \mathrm{~K}$ West facility. The Operations organization shall perform these tests and record the required data under the direction of the Operations Test Director (OTD), who will report to the onduty Shift Manager. The Test Engineer (TE) and Engineering Test Director (ETD) shall support the activities of the OTD. The ETD will have overall technical authority during these tests. The engineers involved with testing activities shall have a PSI Provisional Qualification (Qual Card) and completed OCRWM training.

Facility Engineering shall provide the Shortened Fuel Canister Hook with certified scale. Process Engineering shall provide the Grid Plate, analyze the data collected, and issue a Test Report.

The QA organization shall participate in the verification of performance of the calibration of the scale on the Shortened Fuel Canister Hook. The Safety organization shall provide an AJHA. The Engineering organization shall provide supporting documentation and revisions to this Test Plan.

Radiological Control will address radiological concerns associated with this test activity.

$\mathrm{K}$ Basins Work Control will perform any planning and scheduling activities required to support these tests.

K Basins Maintenance will provide any needed craft support for this activity.

\subsection{SCHEDULE}

This test shall be scheduled by the Job Control System (JCS) and completed in preparation for Phase 3 of the Phased Startup Initiative (PSI).

\subsection{REPORTS}

A copy of the completed Test Procedure (Appendix A) along with the data analysis shall constitute the Test Report. 
SNF-6030, Rev. 0

\subsection{REFERENCES}

Pajunen, A. L., A. L. Pitner, D. W. Smith, 2000, HNF-4898, Rev. 0, Phased Startup Initiative Phases 3 and 4 Test Plan and Test Specifications (OCRWM), February 28, 2000, Fluor Hanford, Inc., Richland, Washington..

\subsection{DATA SHEETS}

Data collection is provided within the Test Procedure in Appendix A. The Pre-Job Safety Briefing Signature Sheet is provided at the end of Appendix A. 
SNF-6030, Rev. 0

SPENT NUCLEAR FUEL PROJECT

WEIGH STATION AND GRID PLATE

TESTING
Procedure No.

Revision No.

Effective Date

Page No.
SNF-6030

$3 / 28 / 00$

1 of 16

\section{APPENDIX A \\ Test Procedure}

Weigh Station and Grid Plate Testing

SNF-6030

Revision No. 0 
SNF-6030, Rev. 0

\section{Table of Contents}

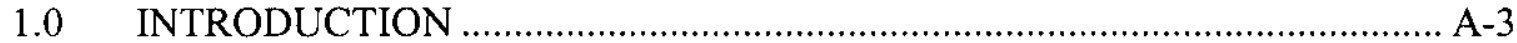

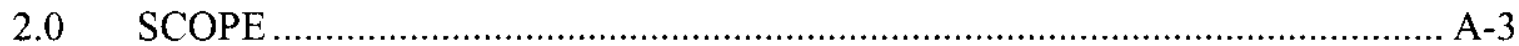

3.0 GENERAL REQUIREMENTS ……........................................................ A-3

4.0 TOOLS, EQUIPMENT, AND SUPPLIES …………………................ A-3

5.0 SAFETY, PRECAUTIONS, AND LIMITATIONS ……………………..... A-4

6.0 INTERFACE REQUIREMENTS .......................................................... A-5

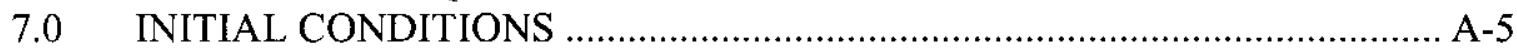

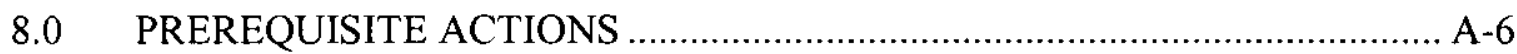

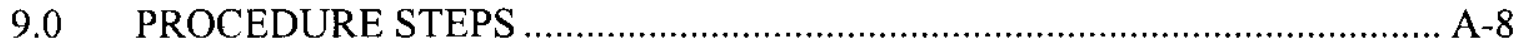

10.0 POST PERFORMANCE ACTIONS …………....................................... A-13

11.0 ACCEPTANCE CRITERIA ……………............................................ A

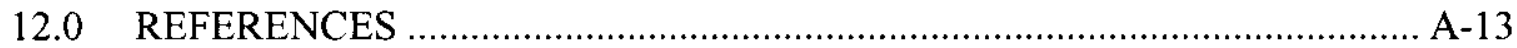

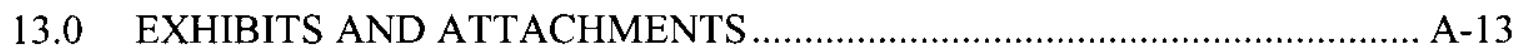

EXHIBIT A. SIGNATURE/INITIAL VERIFICATION …….............................. A-14

EXHIBIT B. TEST EQUIPMENT CALIBRATION LOG ………....................... A-15

EXHIBIT C. PRE-JOB SAFETY BRIEFING SIGNATURE SHEET …………….. A-16

$\begin{array}{ll}\text { AJHA } & \text { Automated Job Hazard Analysis } \\ \text { ALARA } & \text { As Low As Reasonably Achievable } \\ \text { ETD } & \text { Engineering Test Director } \\ \text { I\&C } & \text { Instrumentation and Controls } \\ \text { IWTS } & \text { Integrated Water Treatment System } \\ \text { IXM } & \text { Ion Exchage Module } \\ \text { M\&TE } & \text { Measurement and Test Equipment } \\ \text { OTD } & \text { Operations Test Director } \\ \text { PCM } & \text { Primary Cleaning Machine } \\ \text { QA } & \text { Quality Assurance } \\ \text { QC } & \text { Quality Control } \\ \text { OCRWM } & \text { Office of Civilian Radioactive Waste Mangement } \\ \text { OTD } & \text { Operations Test Director } \\ \text { SNF } & \text { Spent Nuclear Fuel } \\ \text { TD } & \text { Test Director } \\ \text { TSB } & \text { Telescoping Stiff Back }\end{array}$


SNF-6030, Rev. 0

SPENT NUCLEAR FUEL PROJECT WEIGH STATION AND GRID PLATE TESTING
Procedure No.

Revision No.

Effective Date

Page No.
SNF-6030

$3 / 28 / 00$

3 of 16

\subsection{INTRODUCTION}

The purpose of this Test is to verify that the Shortened Fuel Canister Hook with certified Scale (i.e., Weigh Station) can be used to weigh an empty canister from the Canister Well and the empty Primary Cleaning Machine (PCM) Strainer Basket from the Process Table. It is also necessary to verify that the Grid Plate can be lifted and tilted over a canister in the canister well. This testing shall be performed in preparation for the Phase 3 Testing Activities. The Phase 3 Test will repeatedly weight fuel and scrap canisters and the PCM Strainer Basket containing N Reactor fuel. Advance testing of this weigh station will ensure that accurate fuel weight data can be recorded in the Phase 3 Test.

\subsection{SCOPE}

No N-Reactor fuel is involved with this test. Mock fuel is not necessary for this test

\subsection{GENERAL REQUIREMENTS}

3.1 This procedure is under the direct control and supervision of the Operations Test Director (OTD).

3.2 A pretest briefing for all personnel involved in the performance of the test shall be conducted at the beginning of each shift. When new test team members assume test duties, they can be briefed individually. The time and date of each briefing shall be documented in the test log.

3.3 Operations procedures, as applicable, including all safety procedures shall apply to this testing activity. The Test Engineers participating in the performance of this test procedure shall have read and be familiar with, all applicable facility safety procedures prior to initiation of testing activities specified in this procedure. The engineers involved with testing activities shall have a PSI Provisional Qualification (Qual Card) and completed Office of Civilian Radioactive Waste Management (OCRWM) training. A signature sheet attesting to having read the required safety procedures, such as the Automated Job Hazard Analysis (AJHA) or the pretest checklist, as a minimum, is included herein as Exhibit A.

\subsection{TOOLS, EQUIPMENT, AND SUPPLIES}

4.1 Tools

\subsubsection{Pole Hook(s)}


SNF-6030, Rev. 0

SPENT NUCLEAR FUEL PROJECT WEIGH STATION AND GRID PLATE TESTING
Procedure No.

Revision No.

Effective Date

Page No.
SNF-6030

$3 / 28 / 00$

4 of 16

4.2 Equipment

\subsubsection{Grid Plate}

4.2.2 Shortened Fuel Canister Hook with Certified Scale (Weigh Station)

4.3 Supplies

4.3.1 Miscellaneous consumables

5.0 SAFETY, PRECAUTIONS, AND LIMITATIONS

5.1 Personnel

5.1.1 All personnel on the test team shall immediately bring any personnel safety concerns to the attention of the OTD for immediate resolution.

5.1.2 All personnel involved with the performance of this Test shall attend a Pre-job Safety Briefing and sign the Pre-Job Safety Briefing Signature Sheet provided as Exhibit C. The Pre-Job Safety Briefing shall include a review of the AJHA, ALARA requirements and Criticality requirements (including Criticality Postings).

\subsection{Equipment}

5.2.1 If any equipment damage is observed, the OTD shall be notified and the damage evaluated. (Excessive damage may require replacement of equipment before proceeding.)

\subsection{Environment}

5.3.1 During the performance of this test, the requirements for underwater work control and basin water quality found in Process Standard 408 shall be adhered to, i.e.; either the Integrated Water Treatment System (IWTS) is operating or at least a sand filter and one Ion Exchange Module (IXM) are on-line. In addition, the $105 \mathrm{~K}$ West Basin Cs-137 concentration shall be $\leq 10 \mu \mathrm{Ci} / \mathrm{l}$, this can be confirmed with the on-duty shift manager. 
SNF-6030, Rev. 0

SPENT NUCLEAR FUEL PROJECT

WEIGH STATION AND GRID PLATE

TESTING
Procedure No.

Revision No.

Effective Date

Page No.
SNF-6030

$3 / 28 / 00$

5 of 16

\subsection{INTERFACE REQUIREMENTS}

6.1 These testing activities are performed on the Process Table.

6.2 Personnel required to support performance of this test:

\section{Classification}

Test Engineer

Engineering Test Director

Operations Test Director

Operators

I\&C Technician

Health Physics Technician

TOTAL

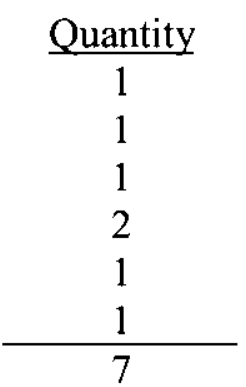

\subsection{INITIAL CONDITIONS}

7.1 The new canister used in this test shall be accepted by Quality Assurance (QA) and approved for use in the Basin (acceptance tagged). A Quality Control (QC) calibration of the scale on the Shortened Fuel Canister Hook shall be completed to determine the accuracy of the scale. A QC certification of the grid squares on the Grid Plate shall be completed. 
SNF-6030, Rev. 0

SPENT NUCLEAR FUEL PROJECT WEIGH STATION AND GRID PLATE TESTING
Procedure No.

Revision No.

Effective Date

Page No.
SNF-6030

0

$3 / 28 / 00$

6 of 16

\subsection{PREREQUISITE ACTIONS}

INITIAL/DATE

Unless otherwise specified, prerequisite actions may be performed in any order.

8.1 All open items have been evaluated and verified to not affect the performance of this test (QA nonconformance reports, construction punch list, outstanding engineering or design change notices, startup field requests or test deficiency reports).

8.2 Perform a walkdown inspection of the systems tested by this procedure.

8.3 Perform an initial briefing for all personnel involved in the performance of this test.

8.4 The TE will determine that appropriate interface support from other organizations is available.

8.5 All personnel who will be involved with this procedure have provided the required signature verification information in Exhibit A.

8.6 All Measurement and Test Equipment (M\&TE) required for this test is listed on Exhibit B, "Test Equipment Calibration Log," and is in the Current calibration cycle.

8.7 Verify that the ETD and OTD are notified prior to commencement of testing (preferably 24 hours).

8.8 Verify that Spent Nuclear Fuel (SNF) QA is notified prior to commencement of testing (preferably 24 hours).
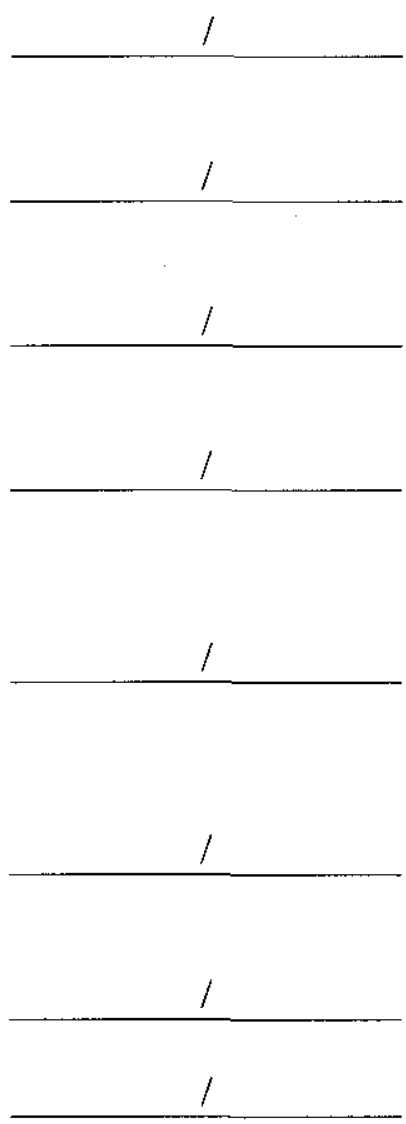

8.9 I have reviewed the above prerequisites and conditions required to commence Section 9.0 to be complete. I recommend that this Test be released for performance.

Engineering Test Director Date 
SNF-6030, Rev. 0

SPENT NUCLEAR FUEL PROJECT

WEIGH STATION AND GRID PLATE

TESTING
Procedure No.

Revision No.

Effective Date

Page No.
SNF-6030

3/28/00

7 of 16

INITIAL/DATE

8.10 I have reviewed the above prerequisites and conditions required to commence Section 9.0 to be complete. This Test is released for performance.

Operations Test Director Date 
SNF-6030, Rev. 0

\begin{tabular}{llr}
\hline SPENT NUCLEAR FUEL PROJECT & Procedure No. & SNF-6030 \\
WEIGH STATION AND GRID PLATE & Revision No. & 0 \\
TESTING & Effective Date & $3 / 28 / 00$ \\
& Page No. & 8 of 16 \\
\hline
\end{tabular}

\subsection{PROCEDURE STEPS}

\begin{tabular}{|c|}
\hline $\begin{array}{l}8.0 \text { PRE- } \\
\text { REQUISITE } \\
\text { ACTIONS }\end{array}$ \\
\hline \\
\hline $\begin{array}{l}9.1 \text { VERIFY } \\
\text { INITIAL } \\
\text { CONDITIONS }\end{array}$ \\
\hline \\
\hline $\begin{array}{l}9.2 \text { WEIGH } \\
\text { EMPTY } \\
\text { CANISTER IN } \\
\text { AIR }\end{array}$ \\
\hline$\downarrow$ \\
\hline $\begin{array}{l}9.3 \text { LIFT AND } \\
\text { TILT GRID } \\
\text { PLATE OVER } \\
\text { CANISTER }\end{array}$ \\
\hline$\downarrow$ \\
\hline $\begin{array}{l}9.4 \text { WEIGH } \\
\text { EMPTY } \\
\text { CANISTER IN } \\
\text { BASIN }\end{array}$ \\
\hline$\downarrow$ \\
\hline $\begin{array}{l}\text { 9.5 WEIGH } \\
\text { PCM } \\
\text { STRAINER } \\
\text { BASKET }\end{array}$ \\
\hline$\nabla$ \\
\hline $\begin{array}{l}10.0 \text { POST } \\
\text { PERFORMANCE } \\
\text { ACTIONS }\end{array}$ \\
\hline
\end{tabular}


SNF-6030, Rev. 0

SPENT NUCLEAR FUEL PROJECT WEIGH STATION AND GRID PLATE TESTING
Procedure No.

Revision No.

Effective Date

Page No.
SNF-6030

$3 / 28 / 00$

9 of 16

INITIAL/DATE

9.1 Verify that the Safety, Precautions, and Limitations of Section 5.0 are complete.

9.2 Observe the Interface Requirements of Section 6.0 are complete.

9.3 Verify that the Initial Conditions and Prerequisites of Sections 7.0 and 8.0 are complete.

9.4 Weigh Empty Canister in Air

9.4.1 Verify Certified Scale Calibration is current by checking date on calibration sticker.

Record Expiration Date:

QA

9.4.2 In air, weigh the approved empty canister without lids using the Weigh Station scale and record the pre-test canister weight:

lb.
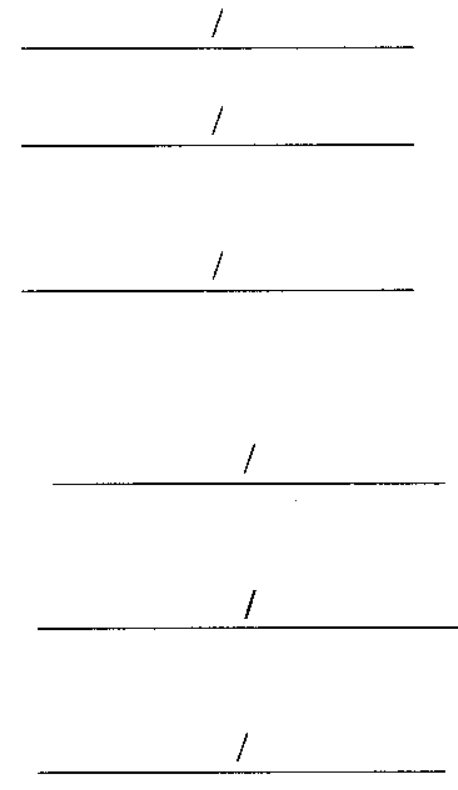

9.4.3 Remove canister well lid from canister well.

9.4.4 Place approved empty canister without lids into basin and position canister in canister well.

9.5 Lift and Tilt Grid Plate Over Canister

9.5.1 Place Grid Plate on Process Table.

9.5.2 Lift Grid Plate and place spout over one canister barrel.

9.5.3 Lift rear bail in order to tilt the Grid Plate over the canister barrel.

9.5.4 Store Grid Plate per OTD instructions.

9.6 Weigh Empty Canister in Basin

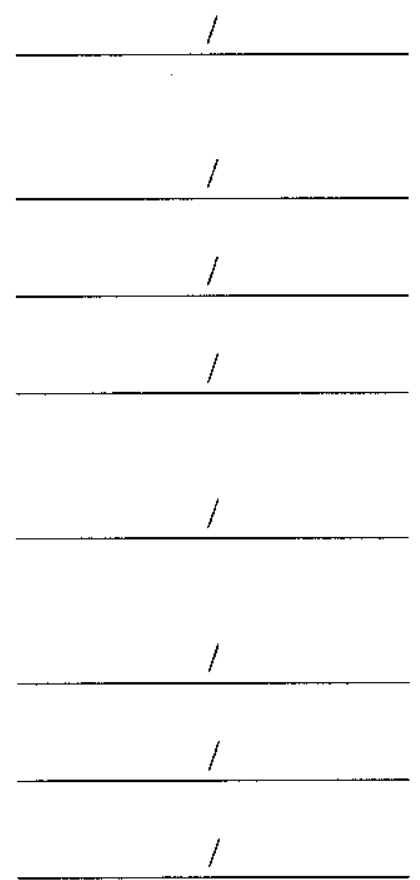


SPENT NUCLEAR FUEL PROJECT WEIGH STATION AND GRID PLATE TESTING
Procedure No.

Revision No.

Effective Date

Page No.
SNF-6030

$3 / 28 / 00$

10 of 16

9.6.1 Record Verification Signature/Date that the weigh

INITIAL/DATE station has been installed at the $105 \mathrm{~K}$ West Basin and is in position above the Process Table.

9.6.2 Record Scale Tare Weight with Shortened Fuel Canister Hook attached:

lb.

9.6.3 Weigh canister with weigh station and record weight:

$\mathrm{lb}$.

9.6.4 Store canister per OTD instructions.

9.6.5 Put canister well lid in place over canister well.

9.7 Weigh PCM Strainer Basket

9.7.1 Remove PCM wash basket by performing the following:

9.7.2 Ensure canister well lid is in place in the north table.

9.7.3 Ensure PCM lid is open.

9.7.4 If PCM lid is not open, then perform the following steps to open lid:

9.7.5 a. Place PCM Lid Oper Maint key switch HS-250PCM-2C in "Oper" position, "Lid Operation" light lit.

b. Place Drive Lock selector switch HS-250-PCM$1 \mathrm{D}$ in "Lock" position, "Drive Locked" light lit.

c. Ensure PCM Drive Lock Cylinder PCM-CYL7251 is locked.
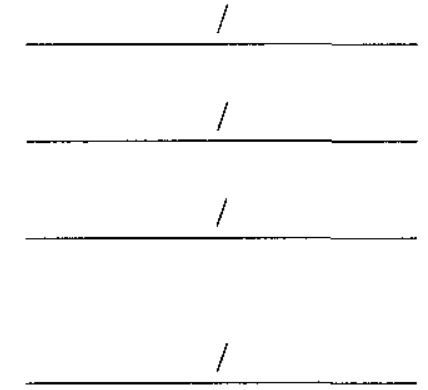

d. Place PCM Basket selector switch HS-250-PCM$2 B$ in "Lock" position, "Basket Locked" light lit.
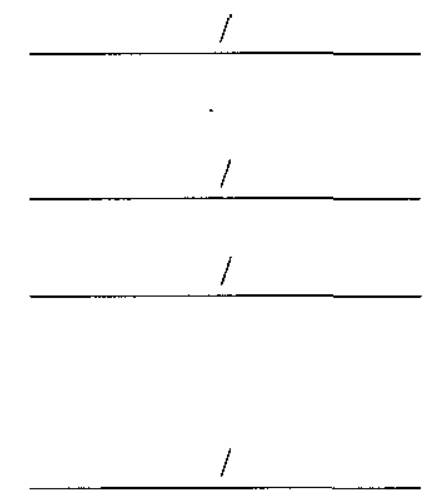
SNF-6030, Rev. 0

e. Place PCM lid selector switch HS-250-PCM-2A

INITIAL/DATE in "Open" position.

f. Ensure PCM lid opened fully

9.7.6 Move north manipulator to safe position and disable.

9.7.7 Engage PCM wash basket with the Telescoping Stiff Back (TSB).

9.7.8 Visually verify proper TSB hook engagement, requires independent confirmation by second operator.

9.7.9 Move wash basket to tipper station with TSB.

9.7.10 Move strainer basket to process table using TSB.

9.7.11 Record Scale Tare Weight: lb.

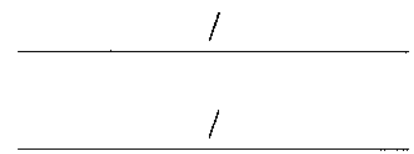

1
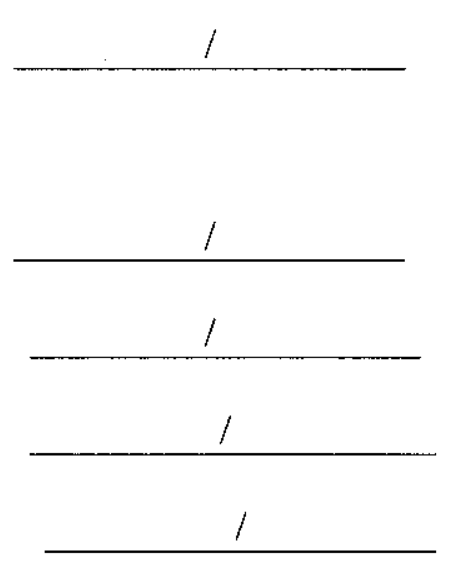

9.7.12 Weigh the PCM Strainer Basket with the Weigh Station and record the PCM Strainer Basket Weight: lb.

9.7.13 Store the Weigh Station per OTD instructions.

9.7.14 Install strainer basket in PCM.

9.7.15 Install wash basket in PCM.

9.7.16 Close PCM lid by performing the following steps:

a. Ensure PCM Lid Oper Maint key switch HS-250PCM-2C in "Oper" position, "Lid Operation" light lit.

b. Place PCM lid selector switch HS-250-PCM-2A in "Closed" Position.

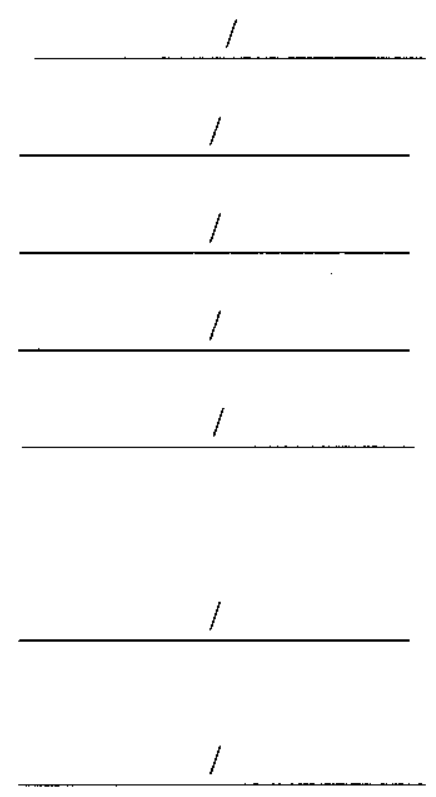


SNF-6030, Rev. 0

SPENT NUCLEAR FUEL PROJECT WEIGH STATION AND GRID PLATE

TESTING
Procedure No.

Revision No.

Effective Date

Page No.
SNF-6030

0

$3 / 28 / 00$

12 of 16

INITIAL/DATE

9.7.17 Ensure PCM lid closed fully by observing "Lid Closed" indicator flag is visible. 
SNF-6030, Rev. 0

SPENT NUCLEAR FUEL PROJECT

WEIGH STATION AND GRID PLATE

TESTING
Procedure No.

Revision No.

Effective Date

Page No.
SNF-6030

$3 / 28 / 00$

13 of 16

\subsection{POST PERFORMANCE ACTIONS}

10.1 The Test Engineer shall verify that this procedure has been completed.

10.2 Performance of testing required by this procedure has been reviewed by the OTD. It is determined that testing required by this procedure is field complete

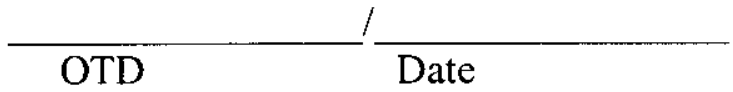

10.3 Process Engineering will analyze the data and issue a test report.

\subsection{ACCEPTANCE CRITERIA}

CRITERIA

11.1 Grid Plate can be lifted and tilted over a canister in the Canister Well.

11.2 The weigh station can be used to lift the canister from the Canister Well, display the weight, and return the canister to the Canister Well.

11.3 The weigh station can be used to lift the PCM Strainer from the Process Table, display the weight, and return the PCM Strainer to the Process Table.

11.4 The weight measurement of a canister submerged in water is compared with the pre-test canister weight in order to determine the weighing uncertainty of the integrated system.

\subsection{REFERENCES}

Pajunen, A. L., A. L. Pitner, D. W. Smith, HNF-4898, Rev. 0, "Phased Startup Initiative Phases 3 and 4 Test Plan and Test Specifications (OCRWM)," March 2000, Fluor Hanford, Richland, Washington.

\subsection{EXHIBITS AND ATTACHMENTS}


SNF-6030, Rev. 0

SPENT NUCLEAR FUEL PROJECT WEIGH STATION AND GRID PLATE TESTING
Procedure No.

Revision No.

Effective Date

Page No.
SNF-6030

$3 / 28 / 00$

14 of 16

\section{EXHIBIT A. SIGNATURE/INITIAL VERIFICATION}

All persons involved in procedure performance, data recording, and verification or evaluation of test steps shall provide their name, job title, signature, and initials in the following table.

\begin{tabular}{|c|c|c|c|c|}
\hline DATE & NAME (PRINT) & TITLE & SIGNATURE & INITIAL \\
\hline & & & & \\
\hline & & & & \\
\hline & & & & \\
\hline & & & & \\
\hline & & & & \\
\hline & & & & \\
\hline & & & & \\
\hline & & & & \\
\hline & & & & \\
\hline & & & & \\
\hline
\end{tabular}


SNF-6030, Rev. 0

SPENT NUCLEAR FUEL PROJECT WEIGH STATION AND GRID PLATE TESTING
Procedure No.

Revision No.

Effective Date

Page No.
SNF-6030

$3 / 28 / 00$

15 of 16

\section{EXHIBIT B. TEST EQUIPMENT CALIBRATION LOG}

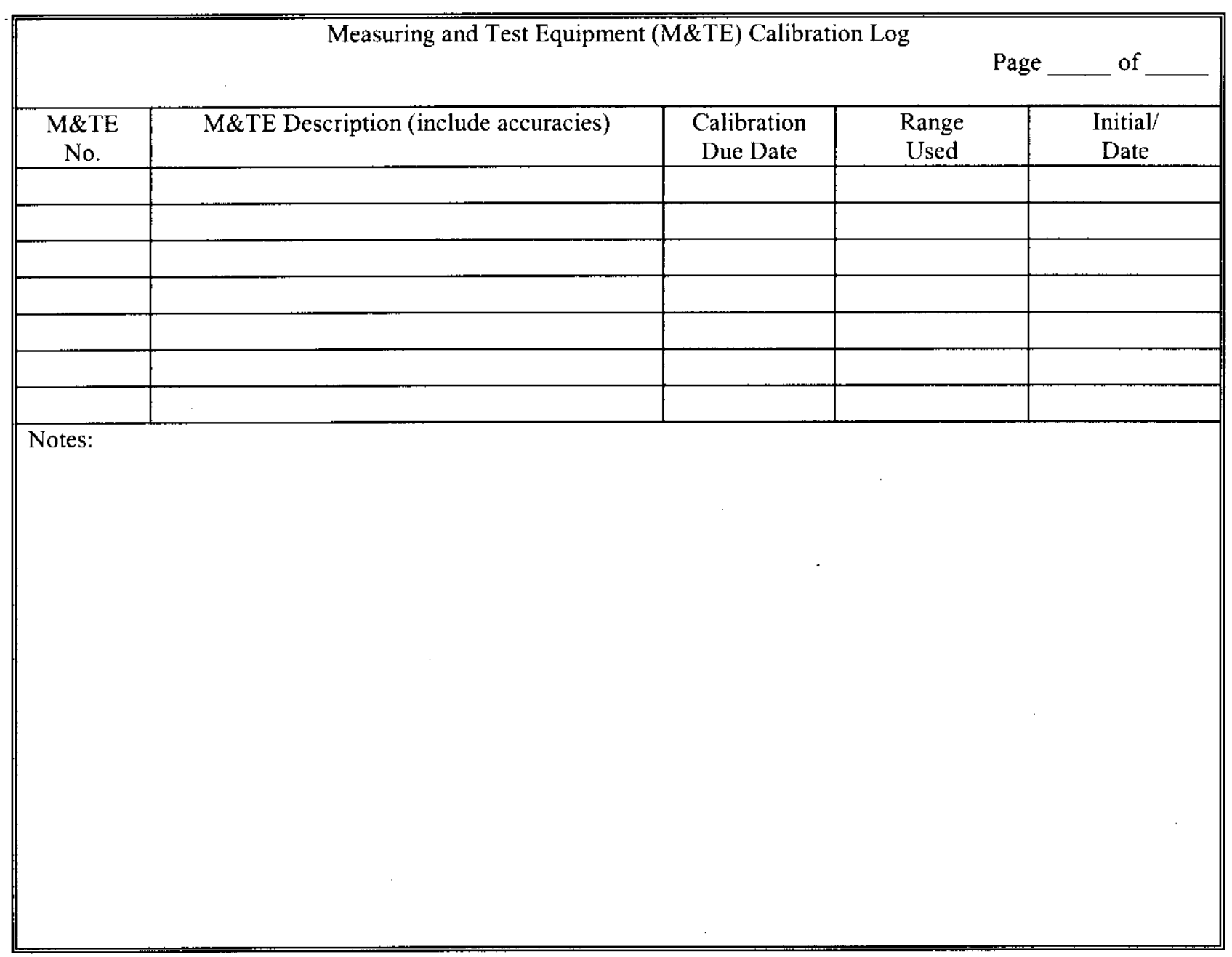


SNF-6030, Rev. 0

SPENT NUCLEAR FUEL PROJECT WEIGH STATION AND GRID PLATE

TESTING
Procedure No.

Revision No.

Effective Date

Page No.
SNF-6030

$3 / 28 / 00$

16 of 16

EXHIBIT C. PRE-JOB SAFETY BRIEFING SIGNATURE SHEET

\begin{tabular}{|c|c|c|c|}
\hline \multicolumn{4}{|c|}{ SPENT NUCLEAR FUEL PROJECT } \\
\hline NAME (PRINTED) & SIGNATURE & INITIALS & DATE \\
\hline & & & \\
\hline & & & \\
\hline & & & \\
\hline & & & \\
\hline & & & \\
\hline & & & \\
\hline & & & \\
\hline & & & \\
\hline & & & \\
\hline & & & \\
\hline & & & \\
\hline & & & \\
\hline & & & \\
\hline & & & \\
\hline & & & \\
\hline
\end{tabular}

